Interdisciplinary Studies of Complex Systems

No. 19 (2021) 59-79

(C) T. Dimitrova, I. Ilieva

https://doi.org/10.31392/iscs.2021.19.059

UDC 378.091.8:659.127.6

\title{
STUDENT BRAND LOYALTY TO PUBLIC HIGHER EDUCATION INSTITUTION
}

\author{
Teofana Dimitrova ${ }^{1}$, Iliana Ilieva ${ }^{2}$
}

\begin{abstract}
The purpose of this study is to investigate and reveal the relationships between student brand loyalty (SBL) and the four composite variables: brand associations (BA), brand information dissemination and sufficiency (BIDS), perceived quality (PQ), student brand engagement (SBE). The paper also explores possible relations between SBE and the constructs BA, BIDS, PQ. An empirical study was conducted among 250 students of 3 faculties in a public university in Bulgaria. The analysis included the maximum likelihood-ratio chi-square test (G-test), correspondence and multiple correspondence analysis. The results demonstrate a significance of all dependences among variables of the research model except between SBE and BA, PQ. Additionally, there has been little work on SBL relationships to select variables. This study contributes to filling this gap in the research. The suggested research frame provides a useful toolkit in aid of higher education policymakers for diagnosing and upgrading the SBL.
\end{abstract}

Keywords: higher education institutions (HEIs), student brand loyalty, student brand engagement

\section{Introduction}

Globalization, internationalization, declining public funding, combined with the rapid development of information and communication technologies, have significantly changed environment for the higher education sector $[1,2]$. Subjected to strong competitive pressure, higher education institutions (HEIs) began to show interest in and focus on "Brand Value Development" in an attempt to get prominent positions in the global market. a new lexis such as branding, brand management, brand identity and brand reputation management was quite naturally assimilated by academia [3].

Research on constructs such as brand strength [4]; brand identity, meaning, image, and reputation [1]; brand ambidexterity and commitment [5, 6]; brand identification [7]; brand personality [8]; brand meaning [9]; employee brand support [10] in higher education in recent years has been increasing but there are still gaps in the student brand loyalty phenomenon that need to be filled [11].

\footnotetext{
${ }^{1}$ Plovdiv University "Paisii Hilendarski", Plovdiv, Bulgaria. teofana.dimitrova@uni-plovdiv.bg, https://orcid.org/0000-0003-1306-185X

${ }^{2}$ University of Food Technologies, Plovdiv, Bulgaria ilieva82@gmail.com, https://orcid.org/0000-0001-8129-9603
} 
The discussion for acknowledging or dismissing students as customers (or consumers) is still ongoing in academia and despite many arguments in favor of student-customer orientation of HEIs, it appears the arguments against are prevalent $[12,13]$. Most likely the reasons for there being so many adversaries of this idea are numerous but the root of such short-sightedness can be found in the archaic understanding that the marketing function is synonymous with sales. Some of the concerns voiced claim that academic standards will be lowered or that it will lead to loss of academic integrity [14]. Over four decades ago Kotler and later Kotler and Andreassen believed that when universities face falling demand they should focus on the customer (i.e. the student) and remarket the product [15]. To HEIs relying on student groups with high loyalty is the key to maintain or win competitive advantages. Student groups with high loyalty gladly recommend certain colleges and universities and by word-of-mouth promote the brand effect. They would continuously support the alma mater after the graduation, including monetary support (donations or sponsoring scientific research projects) and offering employment opportunities or proceeding interview workshops for students in the alma mater [16]. It is imperative that strategies of loyalty be implemented and not simply those of prospecting; gaining new students is not enough, it is necessary that they be retained, by winning their loyalty in the short, medium and long terms [17].

First, the current research comes as a response to certain researchers' call $[11,18,19]$ for the need of increasing the knowledge of student brand loyalty (SBL). By accounting for the validity of theories for brand management for the higher education sector, this paper provides problems to be debated upon and calls towards academia for adopting a unified approach to "student loyalty" for higher education institution. It is our firm belief that using the all-encompassing term "student brand loyalty" is more accurate instead of the indefinite "student loyalty". Adopting a cohesive lexis would decrease any possible misunderstandings and facilitate the function of HEIs marketers. Based on existing insubstantial amount of empiric research on the topic of SBL drivers, we decided to investigate the relation between SBL and four constructs - brand associations (BA), brand information dissemination and sufficiency (BIDS), perceived quality (PQ), student brand engagement (SBE). Furthermore, we tested the supposed mediating role of SBE by testing its relation to BA, BIDS, PQ, SBL. From a theoretical implications point of view, for this particular study a new research model for measuring student brand loyalty was developed. Additionally, even though the research was realized by setting certain limiting conditions like being conducted within a large classical state university in one country, it presents a useful toolkit in aid of higher education policymakers and in other HEIs (particularly in Bulgaria) for diagnosing student associations towards the brand of higher education; exploited communication channels for information in relation to the offered educational programs; the students' intentions for continuation of their education at the same higher education and making recommendation on the brand in front of other target groups. In that regard it offers additional opportunities for more complete realization and focus of the efforts to improve student brand loyalty. 


\section{Conceptual framework}

Increasing competition in the higher education sector (HES) has prompted more and more educational organizations to apply common marketing techniques including brand management [8]. But certainly the embracing of marketing philosophy is not limited to the performance of operational activities such as: (a) to attract the most desirable students and, to a somewhat lesser degree, academic and administrative staff; and (b) to attract government subsidies, research funding, private donations and grants, etc. [20]. There is no doubt that marketing is necessary and applicable for the HE field, but its practical implementation requires taking into account the specifics of the sector. For example, in the business sector, consumer-oriented companies strive to understand and respond to consumer needs better than their competitors. In HES, the educational institutions must have maximum respect to the current and future needs of the society [21], because it is the society as a whole which benefits from the results of the higher education [22]. There is satisfaction of public needs and various interests in stakeholder groups. Higher education is being called upon to create and spread the new knowledge and build high quality human capital. Throughout the world, higher education institutions have key importance for the socioeconomic development and competitiveness of any economy since they are capable of initiating changes in society while remaining the center of change and development [23].

It is argued by some that the primary function of the higher education marketing team is to build the institutional brand [20]. This process can be characterized by different durations for different HEIs while being accompanied by various obstructions. Successful brand management requires a focus on increasing their net value [24]. And as Aaker points out, achieving a certain level of brand loyalty is a key consideration when placing value on a brand [25].

\subsection{Student Brand Loyalty}

The concept of brand loyalty occupies a central place in the study of the consumer-buying process. The research interest is mainly focused on defining the construct and offering reliable instruments for its measurement. In literature, two approaches to defining loyalty are generally distinguished: the stochastic approach, which is purely behavioral, and the attitudinal approach that considers loyalty as an attitude [26]. Probably the most cited definition of brand loyalty is the one of Jacoby and Kyner [27], taking into account a set of six necessary and collectively sufficient conditions: "(1) the biased (i. e. nonrandom), (2) behavioral response (purchase) (3) expressed over time (4) by some decision-making units (5) with respect to one or more alternative brands out of a set of such brands and is (6) a function of psychological (decision-making, evaluative) processes". High brand loyalty is an asset that lends itself to extension, high market share, high return on investment and ultimately high brand equity [28].

The loyalty shown by the students should also be considered from behavioral and attitudinal perspectives, because they are in fact the real users of the educational product produced by HEI. What is it exactly that students show loyalty towards? This was the first question that intrigued us at the onset of 
our work on this research. a look through literature shows finding an answer is not that easy. It turns out that student loyalty has a broad spread, e.g. in relation to curriculum [29], educational programs [30], educational institution [31, 32, 33, 34], HEI brand [11, 18]. This provides a platform for thinking about a loyalty continuum. We believe it is more accurate when addressing "student loyalty to the HEI" to use "student brand loyalty". Our reasoning is that the higher education institution brand is viewed as a complex symbolic construct carrying a denotative (signifying, specifying a certain phenomenon) function and connotative (fulfilling, suggesting, invoking feelings and attitude towards a certain phenomenon) function. In that regard it includes the institution name, logo, slogan, human capital, academic and scientific achievements of the academic personnel, methods of teaching, administrative service, technical material and information base, affiliation to an academic society, the promise of professional realization et al. Within a business environment of increasing similarities among offered educational programs, subjects being studied (which may be regulated by the accrediting body in a country due to requirements for accepting periods of studying in other higher schools), non-exclusiveness of academic staff (professors' affiliation in several universities), similar tuition fees et al, competitive relations among higher schools ascend to a newer level and become about brands, i. e. a shift of accent occurs in searching and building competitive advantages, starting from product attributes (such as quality of education) towards improving the public prestige and image and creating a higher level of loyalty towards the higher school brand. How many and which of the brand attributes would HEI choose to target is decisive to the future expected outcome. It is certain that higher education institutions by no means cannot, nor would want to, remain anonymous. It is precisely the HEI brand names which can be found in numerous rankings, guides and report cards and separate stakeholder groups researching which university, to simplify, is the best; in teaching and/or research, in a particular country, or within a region on TV, newspapers or on the internet [35].

\subsection{Drivers of Student Brand Loyalty}

Some authors determine that knowledge about the drivers influencing student loyalty is of great strategic importance to the institutions of higher education [36]. Several possible drivers of student loyalty and university brand loyalty/HEIs brand loyalty have been discussed previously and this study builds on previous research $[7,11,18,30,31,37,38,39]$, that focused on relationships between student loyalty and trust in institution/personnel, emotional commitment to the institution, perceived quality of teaching, student satisfaction, relationship quality, student engagement, brand experience, university performance, brand attitude, intensity of use, brand support, brand associations, brand information dissemination and sufficiency, brand love.

The present study does not seek an answer to the question which the drivers of student brand loyalty are, but aims to verify the existence of relationships between SBL and the selected composite variables. That is, it can be defined as preceding. This paper develops a conceptual framework of student brand loyalty, as shown in Fig. 1. 


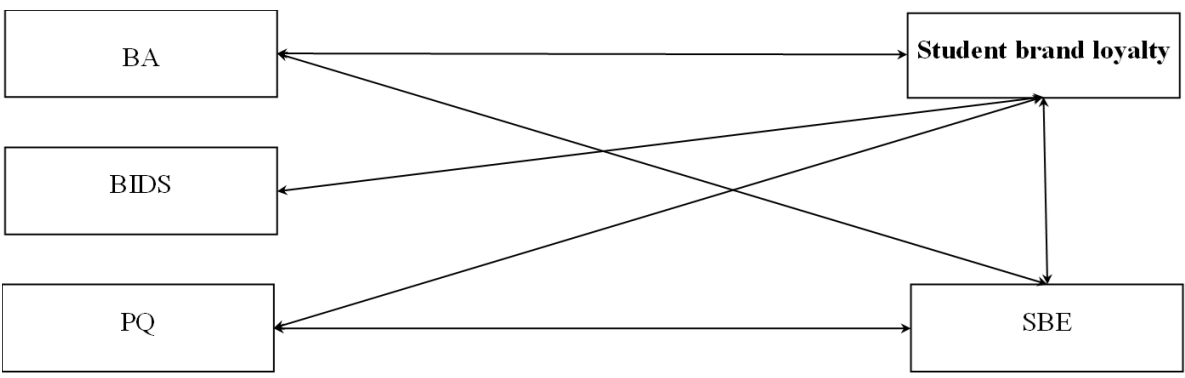

Fig. 1. Conceptual model for SBL

Brand Associations Perhaps the most cited definition of a brand association is that of Aaker [40], who defines it as anything "linked" in customers' memory to a brand. Some perceive it as an information collecting tool [41]. Like Aaker, Keller [42] argues, brand associations take different forms. According to their level of abstraction, he distinguishes three major categories of increasing scope: attributes, benefits, and attitudes.

In HE field the students' associations for the brand of the educational institution can be influenced by their values and caused by their contacts with alumni members, professors, employees of business organizations, parents et al, stakeholders, advertising and PR activities of HEI, price of the received educational service, publicly accepted and exploited connotations of the institutional brand, perceived level of the future risk of the educational choices, etc. Studying brand associations can help HEI building university brand identification, achieving a competitively attractive brand position, extending the brand in other geographical regions and more.

Brand information dissemination and sufficiency There is widespread agreement among researchers that brand communication contributes to brand recognition, formation of trust and satisfaction with the brand. It is divided into two types: one-way communication and two-way communication, or indirect or direct communication, respectively. In one-way communication, the main focus is enhancing brand awareness, brand attitudes, and purchasing behavior [43]. The information assurance of the brand plays a key role in the process of its development, implementation, maintenance and protection. Here, the efforts of branding professionals should be focused on the nature of the brand information that the institution aims to disseminate and on the type and number of communication channels that will ensure it.

The brand information must: (a) be accessible to recipients (b), assist in establishing the desired brand associations, (c) be characterized by a volume that can be stored in the user's memory for a given period of time, (d) has a degree of sufficiency to provoke attitude or action.

Perceived quality According to Parasuraman et al. [44, 45] perceived service quality is "the result of the consumer's comparison of expected service with perceived service". It is a form of attitude, which is similar to but not equivalent to satisfaction. To Aaker [40] perceived quality is "intangible, overall feeling about a brand". When consumers value brand attributes as high 
quality, they are likely to put a high value on the brand, driving their purchase and repurchase decisions [46]. Previous studies show that perceived quality is among the important drivers of brand loyalty [47, 48].

In HES there is an emphasis on the activities for maintaining and improving the quality of education received by students. This emphasis is also present in government programs, public demands by parents, discussions with employer representatives, normative requirements by the accrediting institutions, et al. In that regard, it is natural for the management of educational institutions to strive to enhance the level of perceived service quality among the various stakeholders. The discussion about perceived quality in HES is too broad, but the current study focuses only on students who are the main source of responses toward service quality. The literature indicates that there is a direct relationship between the level of perceived service quality and student loyalty [33, 34]. Here it is extremely important what the choice of components of perceived quality in HES is, which will be measured. There is no single opinion on the type and number of these components due to the multiple aspects of the term itself. For example, Purgailis and Zaksa [49] divide the quality factors into four parts: result "quality"; process "quality"; staff "quality"; environment "quality". Calvo-Porral et al. [50] adapt for the field of higher education the SERVQUAL model of Parasuraman et al., offering five dimensions for measuring perceived quality: tangibles; reliability; responsiveness; assurance; empathy.

Student brand engagement The concept of student engagement has enjoyed considerable attention among those aiming to enhance learning and teaching in higher education for over twenty years [51]. There is an optimistic expectation that through the engagement process, the students' ability to learn how to learn and how to become lifelong learners in a knowledge-based society is improved [52]. Matthews [53] argues however, that "engaging students is not enough". He suggests that students should be seen as partners and partnerships with them in practice take shape around collaborative activities whereby students and academics/staff are: (a) engaged in learning, teaching, curricula and assessment activities, and (b) engaged in quality enhancement efforts to enhance the educational enterprise.

Although in recent years this concept has gained particular popularity and has been researched in the consumer behavior domain, there is a dearth of empirical studies focusing on the role of customer brand engagement (CBE) $[54,55,56,57]$. It is believed that brand engagement can contribute to improving organizational results such as sales growth, cost reductions, superior profitability, enhanced consumer contributions toward the collaborative product development processes, brand referrals and enhanced co-creative experiences [58]. In recent years CBE has been examined by a number of researchers in various areas of services, such as mobile phone services [59], the hospitality sector [60], the hotel industry [57] and others, but in the field of higher education student brand engagement it is still underresearched [61]. For the purposes of the present study, the definition given by Hollebeek [62] for CBE has been adapted and further developed. Thus, student brand engagement is understood as: the students' cognitive, emotional and behavioral investment in HEI brand interactions, manifested at a certain time, with varying degrees of intensity 
and focus. This paper assumes that HEI brand interactions evoke feelings of empathy and pride, enrichment of knowledge and behavioral response. Keller's vision of the various aspects of brand loyalty is also shared, distinguishing between "sense of community" and "active engagement" [63]. Sense of community is the feeling of affiliation with other people associated with the brand, while active engagement is the willingness of customers to invest personal resources in the brand (time, energy, money, etc. - beyond the resources expended during the purchase or consumption of the brand).

Therefore, we propose the following hypotheses:

Hypothesis 1a. There is a relationship between brand associations and student brand loyalty.

Hypothesis $1 \mathrm{~b}$. There is a relationship between brand associations and student brand engagement. loyalty.

Hypothesis 2a. There is a relationship between BIDS and student brand

Hypothesis 2b. There is a relationship between BIDS and student brand engagement.

Hypothesis 3a. There is a relationship between perceived quality and student brand loyalty.

Hypothesis 3b. There is a relationship between perceived quality and student brand engagement.

Hypothesis 4 . There is a relationship between student brand engagement and student brand loyalty.

\section{Methodology}

\subsection{Design: Survey Context and Data Collection}

The current empirical study was executed in two phases. In the first phase, a pilot study was conducted among 60 current students of Plovdiv University "Paisii Hilendarski" (PU), the second largest classical type of public university in Bulgaria with accredited 27 professional majors in 6 fields of higher education. This pilot phase tested the developed tools and procedure. Upon its finalization, s ome questions a nd a nswers w ere $\mathrm{r}$ educed a nd $\mathrm{r}$ efined. In its second phase, the survey covered 250 statistical units, selected on the basis of 2 quota categories - faculty and year of study in PU. Purposive sampling was used to collect sample of this study. The total respondents in this study was 250 who were students in third- and fourth-year bachelor's specialties from the three faculties of the university. After screening the total remaining sample of this research was 205 respondents. Data was collected between January 2021 and March 2021.

\subsection{Questionnaire Design and Measures}

The questionnaire was prepared online and it included three main parts: introduction and purpose of the survey; measurement items; and demographic information. Variables which were chosen for observation of the constructs brand associations, brand information dissemination and sufficiency, student brand engagement, student brand loyalty and formulated questions, are illustrated in Table 1. 
Table 1. Variables and formulated questions

\begin{tabular}{|c|c|c|}
\hline Construct & Variable & Questions \\
\hline \multirow[t]{2}{*}{ BA } & $\begin{array}{l}\mathrm{BA}- \\
\text { identifiers } \\
(\mathrm{BA} 1)\end{array}$ & $\begin{array}{l}\text { What do you relate PU with? } \\
\text { BA1.1: second largest university in Bulgaria } \\
\text { BA1.2: elite HEI } \\
\text { BA1.3: high quality education } \\
\text { BA1.4: variety of majors } \\
\text { BA1.5: good social environment } \\
\text { BA1.6: other }\end{array}$ \\
\hline & $\begin{array}{l}\mathrm{BA}- \\
\text { motivators } \\
(\mathrm{BA} 2)\end{array}$ & $\begin{array}{l}\text { Why did you choose to study at PU? } \\
\text { BA2.1: is a state higher education institution } \\
\text { BA2.2: has a good reputation } \\
\text { BA2.3: offers accessible tuition fees } \\
\text { BA2.4: has a high public prestige } \\
\text { BA2.5: I expect a certain professional } \\
\text { realization } \\
\text { BA2.6: other }\end{array}$ \\
\hline \multirow[t]{2}{*}{ BIDS } & $\begin{array}{l}\text { Communi- } \\
\text { cation } \\
\text { channels } \\
\text { (BIDS1) }\end{array}$ & $\begin{array}{l}\text { Where do you receive information about PU } \\
\text { from? } \\
\text { BIDS1.1: the university web site } \\
\text { BIDS1.2: professors } \\
\text { BIDS1.3: social networks } \\
\text { BIDS1.4: other } \\
\text { BIDS1.5: from nowhere }\end{array}$ \\
\hline & $\begin{array}{l}\text { Sufficiency } \\
\text { of } \\
\text { information } \\
\text { (BIDS2) }\end{array}$ & $\begin{array}{l}\text { Was there sufficient information about the } \\
\text { education opportunities in } P U \text { at the time } \\
\text { you applied? } \\
\text { BIDS2.1: yes } \\
\text { BIDS2.2: no } \\
\text { BIDS2.3: I cannot decide }\end{array}$ \\
\hline \multirow[t]{2}{*}{ SBE } & $\begin{array}{l}\text { Interest } \\
\text { (SBE1) }\end{array}$ & $\begin{array}{l}\text { Do you have information about: } \\
\text { SBE1.1: professors' public appearances } \\
\text { SBE1.2: professors' publications } \\
\text { SBE1.3: R\&D within the faculty } \\
\text { SBE1.4: R\&D within the university } \\
\text { SBE1.5: I am not aware of any of the above }\end{array}$ \\
\hline & $\begin{array}{l}\text { Partici- } \\
\text { pation } \\
(\mathrm{SBE} 2)\end{array}$ & $\begin{array}{l}\text { Have you participated in: } \\
\text { SBE2.1: the learning process } \\
\text { SBE2.2: R\&D within university } \\
\text { SBE2.3: I have not participated }\end{array}$ \\
\hline
\end{tabular}




\begin{tabular}{|c|c|c|}
\hline Construct & Variable & Questions \\
\hline \multirow[t]{3}{*}{ SBL } & $\begin{array}{l}\text { First-choice } \\
\text { brand } \\
\text { decision } \\
\text { (SBL1) }\end{array}$ & $\begin{array}{l}\text { If I you were a student applicant now, will } \\
\text { you choose: } \\
\text { SBL1.1: the same major in PU } \\
\text { SBL1.2: the same major in another HEI } \\
\text { SBL1.3: a different major in PU } \\
\text { SBL1.4: a different major in another HEI } \\
\text { SBL1.5: I cannot decide }\end{array}$ \\
\hline & $\begin{array}{l}\text { Further } \\
\text { education } \\
\text { (SBL2) }\end{array}$ & $\begin{array}{l}\text { Will you continue your education at the } \\
\text { University of Plovdiv in: } \\
\text { SBL2.1: Master's Program } \\
\text { SBL2.2: another bachelor's program } \\
\text { SBL2.3: doctoral program } \\
\text { SBL2.4: neither of the above }\end{array}$ \\
\hline & $\begin{array}{l}\text { Brand } \\
\text { recommen- } \\
\text { dation } \\
\text { (SBL3) }\end{array}$ & $\begin{array}{l}\text { Will you advise friends and/or relatives } \\
\text { to apply to PU: } \\
\text { SBL3.1: yes } \\
\text { SBL3.2: no } \\
\text { SBL3.3: I cannot decide }\end{array}$ \\
\hline \multirow{12}{*}{$\mathrm{PQ}$} & \multicolumn{2}{|c|}{$\begin{array}{l}\text { Thinking about your experience with this university, please indi- } \\
\text { cate answering your agreement/disagreement with the following } \\
\text { statements, using the scale from "strongly agree" (1) to "strongly } \\
\text { disagree" }(5) \text {. }\end{array}$} \\
\hline & \multicolumn{2}{|c|}{$\begin{array}{l}\text { Provision of administrative services at the Plovdiv University } \\
\text { is at a good level }\end{array}$} \\
\hline & \multicolumn{2}{|c|}{ Contents of Academic Standards of Courses is student-friendly } \\
\hline & \multicolumn{2}{|c|}{ Courses studied are practice-oriented } \\
\hline & \multicolumn{2}{|c|}{ Objective assessment of student performance } \\
\hline & \multicolumn{2}{|c|}{ Academic study plans are fit to student preferences } \\
\hline & \multicolumn{2}{|c|}{ Academic Faculty \& Staff are highly qualified } \\
\hline & \multicolumn{2}{|c|}{$\begin{array}{l}\text { University Management \& Administration provide the neces- } \\
\text { sary expert aid to students }\end{array}$} \\
\hline & \multicolumn{2}{|c|}{$\begin{array}{l}\text { Academic Literature in the University Library is at deemed sat- } \\
\text { isfactory }\end{array}$} \\
\hline & \multicolumn{2}{|c|}{ Good quality of the Wi-Fi connection at the University } \\
\hline & \multicolumn{2}{|c|}{ Good quality of life on the campus } \\
\hline & \multicolumn{2}{|c|}{ The University provides disabled-friendly environment } \\
\hline
\end{tabular}

For the measurement of BA, 2 types of brand associations were selected (brand identifiers and motivators for making an educational choice). The key associations for HEI established by the first phase of the research were set at this phase - being the second largest university, elite HEI, high quality education, the variety of specialties, good social environment, state HEI, good institutional reputation, accessible tuition fees, high public prestige and expectations of professional realization. 
BIDS was measured according to 2 variables - communication channels of the HEI brand and sufficiency of information about the educational and socio-cultural activities of the educational institution, proposed by [38].

SBE was measured by 2 variables - interest (in public appearances and professors' publications, research and development (R\&D) activity within the faculty/PU, including scientific projects and obtained results) and participation (in the learning process, including discussions of curricula, change of roles between students and professors; research activity in PU), adopted from [51].

SBL was measured by 3 variables - first-choice brand decision, intention of further education and propensity to recommend the brand adopted from [18].

PQ was evaluated by 11 items with respect to the following dimensions: quality of academics, quality of administration, quality of infrastructure, quality of examinations, quality of social life, quality of student care adopted from [32]. All items were measured on a five-point Likert-scale, which ranges from "strongly agree" (1) to "strongly disagree" (5).

\section{Results}

The maximum likelihood ratio chi-squre test (G-test) was used to confirm or reject the associations between the selected categorical variables. Notable findings among the confirmed relationships were discussed and graphically depicted with the assistance of a correspondence (CA) and multiplecorrespondence analysis (MCA) to display the associations between the levels of the variables. CA and MCA were considered using the symmetrical normalization and variable principal normalization method, respectively. All statistical analyses were performed with SPSS (version 24.0). The significance level was set at $p$-value less of 0.05 . This paper assumes that if all associations with respect to a given hypothesis are significant, then the hypothesis is fully accepted. In the case of more than $50 \%$ significant associations, the hypothesis is partially accepted, and in $50 \%$ or less it is not accepted. Of interest for the present study are only the relationships between the selected composite variables and the levels of SBL, indicating a manifestation of attitudinal and behavioral loyalty (via SBL1.1, SBL1.3, SBL2.1-SBL2.3 and SBL3.1).

The results showed that all of the associations referred to H1a were significant, while significant one referred to H1b were only $25 \%$ (see Table 2). Therefore, H1a was fully supported and H1b was not supported.

Table 2. Associations between BA and SBL, BA and SBE

\begin{tabular}{|c|c|c|c|}
\hline \multicolumn{2}{|c|}{ H1a } & \multicolumn{2}{c|}{ H1b } \\
\hline Variables & $p$-value & Variables & $p$-value \\
\hline BA1-SBL1 & $\mathbf{0 . 0 0 0}$ & BA1-SBE1 & 0.451 \\
\hline BA1-SBL2 & $\mathbf{0 . 0 0 2}$ & BA1-SBE2 & 0.998 \\
\hline BA1-SBL3 & $\mathbf{0 . 0 0 0}$ & BA2-SBE1 & $\mathbf{0 . 0 3 4}$ \\
\hline BA2-SBL1 & $\mathbf{0 . 0 2 2}$ & BA2-SBE2 & 0.998 \\
\hline BA2-SBL2 & $\mathbf{0 . 0 4 1}$ & - & - \\
\hline BA2-SBL3 & $\mathbf{0 . 0 2 3}$ & - & - \\
\hline \multicolumn{2}{|c|}{$p<0.05$ is marked in bold. }
\end{tabular}




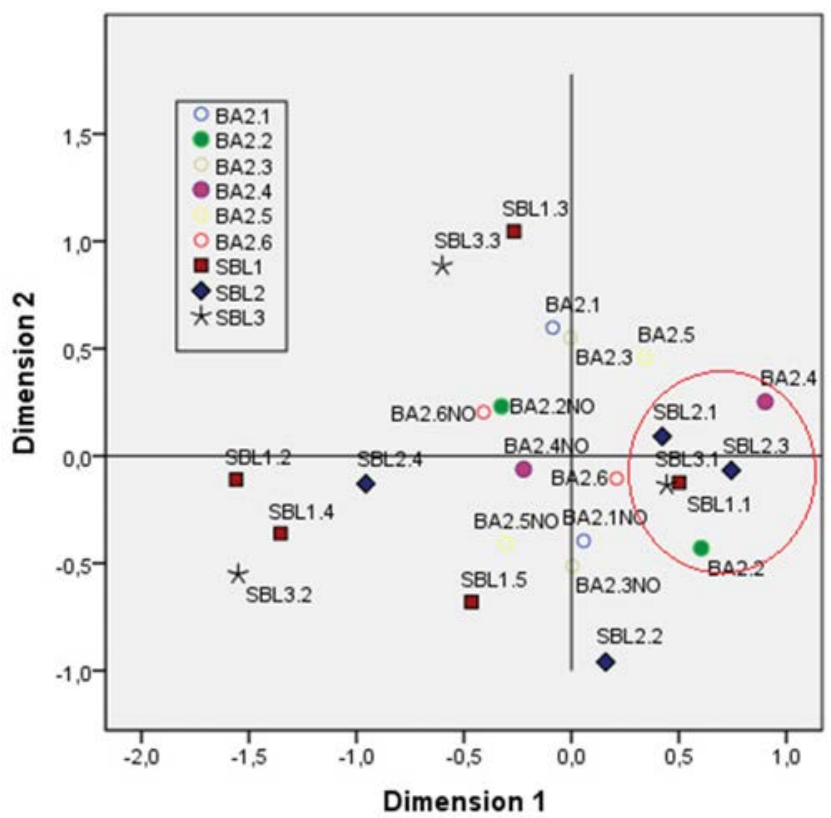

Fig. 2. Joint plot of category points, displaying relationship among the categories of BA and SBL

A MCA was conducted to show the relationship between the levels of BA2 and SBL. BA2 are essential to BA1 because they are the motivators of the HEI brand choice.

From the analysis, a two-dimension MCA solution was considered. The first and second dimensions presented are, respectively, inertia 0.223 and 0.145 and Cronbach's alpha, 0.565 and 0.261. Although the generally accepted lower limit for Cronbach's alpha is 0.70 , a smaller value is acceptable in exploratory research [64]. As can be seen from Fig. 2, those of the respondents who would stay with their initial educational choice intend to continue their education in a master's or doctoral program at the University of Plovdiv. They were motivated to study at the University of Plovdiv because of its good reputation and high public prestige.

As can be seen from Table 3, there is a more significant relationship among the results (about $67 \%$ among those for $\mathrm{H} 2 \mathrm{a}$ and $75 \%$ for $\mathrm{H} 2 \mathrm{~b}$ ). Thus, the validity of $\mathrm{H} 2 \mathrm{a}$ and $\mathrm{H} 2 \mathrm{~b}$ was partially supported.

Table 3. Associations between BIDS and SBL, BIDS and SBE

\begin{tabular}{|c|c|c|c|}
\hline \multicolumn{2}{|c|}{ H2a } & \multicolumn{2}{c|}{ H2b } \\
\hline Variables & $p$-value & Variables & $p$-value \\
\hline BIDS1 - SBL1 & 0.147 & BIDS1-SBE1 & $\mathbf{0 . 0 0 0}$ \\
\hline BIDS1 - SBL2 & 0.444 & BIDS1 - SBE2 & $\mathbf{0 . 0 0 3}$ \\
\hline BIDS1 - SBL3 & $\mathbf{0 . 0 2 2}$ & BIDS2 - SBE1 & $\mathbf{0 . 0 3 5}$ \\
\hline BIDS2 - SBL1 & $\mathbf{0 . 0 2 1}$ & BIDS2 - SBE2 & 0.408 \\
\hline BIDS2 - SBL2 & $\mathbf{0 . 0 2 3}$ & - & - \\
\hline BIDS2 - SBL3 & $\mathbf{0 . 0 1 2}$ & - & - \\
\hline$p<0.05$ is marked in bold. & & \\
\hline
\end{tabular}


A CA was run to graphically examine the relationships between BIDS and SBL3. The model was not absolutely good but adequate with total inertia value of 0.023 (accounted for 0.85 by dimension 1 and for 0.15 by dimension 2) and $\chi^{2}=21.62, \mathrm{p}=0.006$. Based on the $\mathrm{CA}$, respondents who would recommend the PU brand are informed by the university website and professors (see Fig. 3).

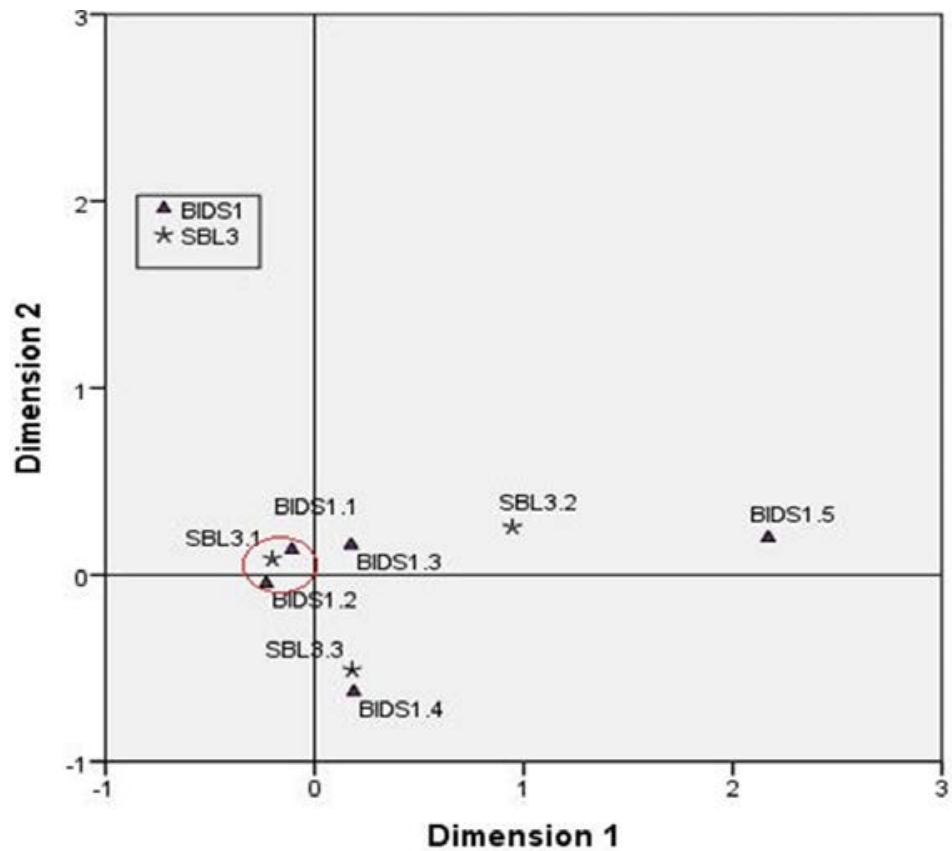

Fig. 3. CA displaying relationship among the categories of BIDS1 and SBL3

According to the results in Table $4,76 \%$ of all associations related with H3a were significant and $14 \%$ related with H3b were not significant. Hence, H3a was partially supported and H3b was not supported.

Table 4. P-value for associations between PQ and SBL, PQ and SBE

\begin{tabular}{|c|c|c|c|c|c|}
\hline & \multicolumn{3}{|c|}{ H3a } & \multicolumn{2}{c|}{ H3b } \\
\cline { 2 - 6 } & $S B L 1$ & $S B L 2$ & $S B L 3$ & $S B E 1$ & $S B E 2$ \\
\hline PQ1 & 0.411 & 0.183 & $\mathbf{0 . 0 0 0}$ & 0.791 & 0.563 \\
\hline PQ2 & $\mathbf{0 . 0 0 0}$ & $\mathbf{0 . 0 0 8}$ & $\mathbf{0 . 0 0 0}$ & 0.185 & 0.665 \\
\hline PQ3 & $\mathbf{0 . 0 0 0}$ & $\mathbf{0 . 0 2 5}$ & $\mathbf{0 . 0 0 0}$ & $\mathbf{0 . 0 0 3}$ & 0.467 \\
\hline PQ4 & $\mathbf{0 . 0 0 7}$ & $\mathbf{0 . 0 0 2}$ & $\mathbf{0 . 0 0 0}$ & 0.057 & 0.939 \\
\hline PQ5 & $\mathbf{0 . 0 1 7}$ & 0.063 & $\mathbf{0 . 0 2 0}$ & 0.851 & 0.672 \\
\hline PQ6 & $\mathbf{0 . 0 0 5}$ & $\mathbf{0 . 0 0 0}$ & $\mathbf{0 . 0 0 0}$ & 0.524 & 0.701 \\
\hline PQ7 & $\mathbf{0 . 0 0 3}$ & $\mathbf{0 . 0 0 3}$ & $\mathbf{0 . 0 0 1}$ & $\mathbf{0 . 0 0 6}$ & 0.067 \\
\hline PQ8 & 0.113 & 0.063 & 0.087 & 0.577 & 0.317 \\
\hline PQ9 & $\mathbf{0 . 0 0 1}$ & $\mathbf{0 . 0 2 4}$ & $\mathbf{0 . 0 0 6}$ & $\mathbf{0 . 0 2 0}$ & 0.739 \\
\hline PQ10 & $\mathbf{0 . 0 0 0}$ & $\mathbf{0 . 0 0 1}$ & $\mathbf{0 . 0 0 0}$ & 0.085 & 0.469 \\
\hline PQ11 & 0.347 & 0.100 & $\mathbf{0 . 0 0 9}$ & 0.446 & 0.387 \\
\hline$p<0.05$ & marked in bold. \\
\hline \multicolumn{7}{|l|}{}
\end{tabular}


The relationship between the levels of SBL and PQ was depicted executing a MCA. Again a two-dimension MCA solution was considered. The first and second dimensions presented are, respectively, inertia 0.342 and 0.277 and Cronbach's alpha, 0.852 and 0.800 . Thus, the following MCA results can be summarized. Those of the respondents who would stay with their initial educational choice and intend to continue their education in a master's program highly value the following aspects: provision of administrative services; contents of academic standards of student friendly courses; studied subjects' practicality; marking objectiveness; curriculum convenience; professors' qualifications; level of student care; infrastructure quality (internet, libraries, accessibility for the disabled, et al); social environment quality (see Fig. 4).

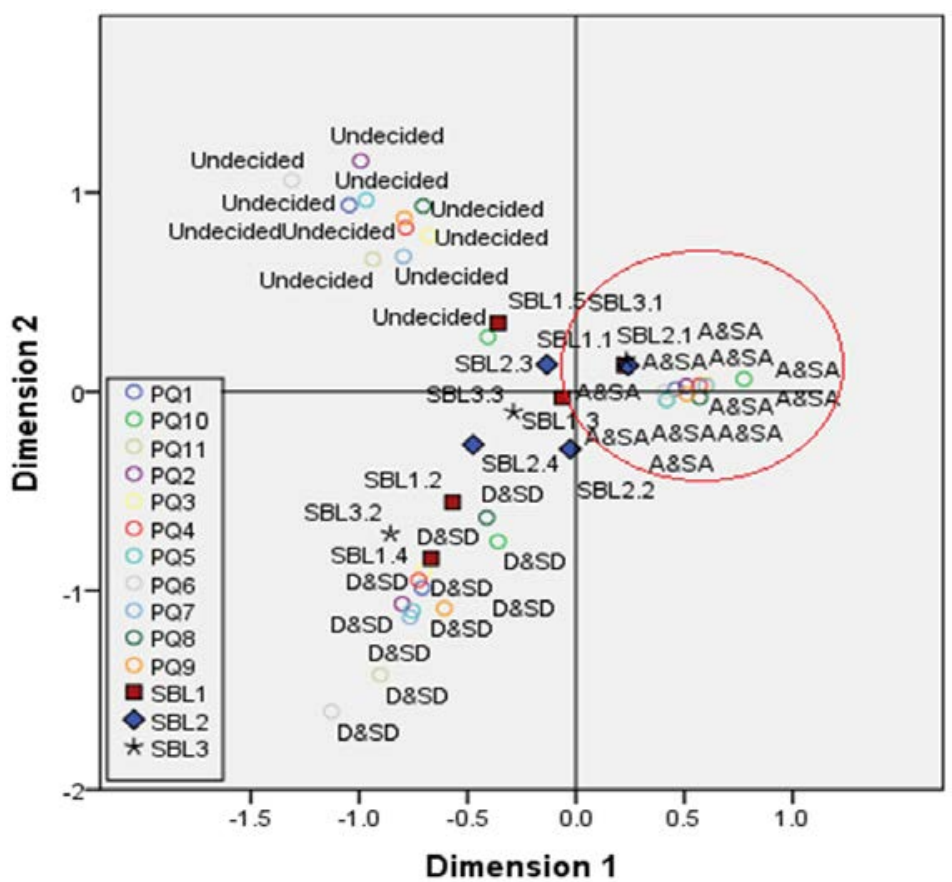

Fig. 4. Joint plot of category points, displaying relationship among the categories of SBL and PQ

Based on the results shown in Table 5, 67\% of the associations referring to H4 were significant. Thus, H4 was partially supported.

Table 5. Association between SBE and SBL

\begin{tabular}{|c|c|}
\hline \multicolumn{2}{|c|}{ H4 } \\
\hline Variables & $p$-value \\
\hline SBE1 - SBL1 & 0.864 \\
\hline SBE1 - SBL2 & $\mathbf{0 . 0 0 0}$ \\
\hline SBE1 - SBL3 & $\mathbf{0 . 0 3 6}$ \\
\hline SBE 2-SBL1 & 0.371 \\
\hline SBE 2-SBL2 & $\mathbf{0 . 0 0 3}$ \\
\hline SBE 2-SBL3 & $\mathbf{0 . 0 0 0}$ \\
\hline$p<0.05$ is marked in bold \\
\hline
\end{tabular}


A CA was performed to graphically examine the relationships between SBE2 and SBL2 (see Fig. 5). The total inertia value is 0.031 (accounted for 0.917 by dimension 1 and for 0.083 by dimension 2 ) and $\chi^{2}=17.106, p=0.009$. Based on the CA, participation in the R\&D activity of the University of Plovdiv is registered for those respondents who would continue their education in a master's program at the University of Plovdiv.

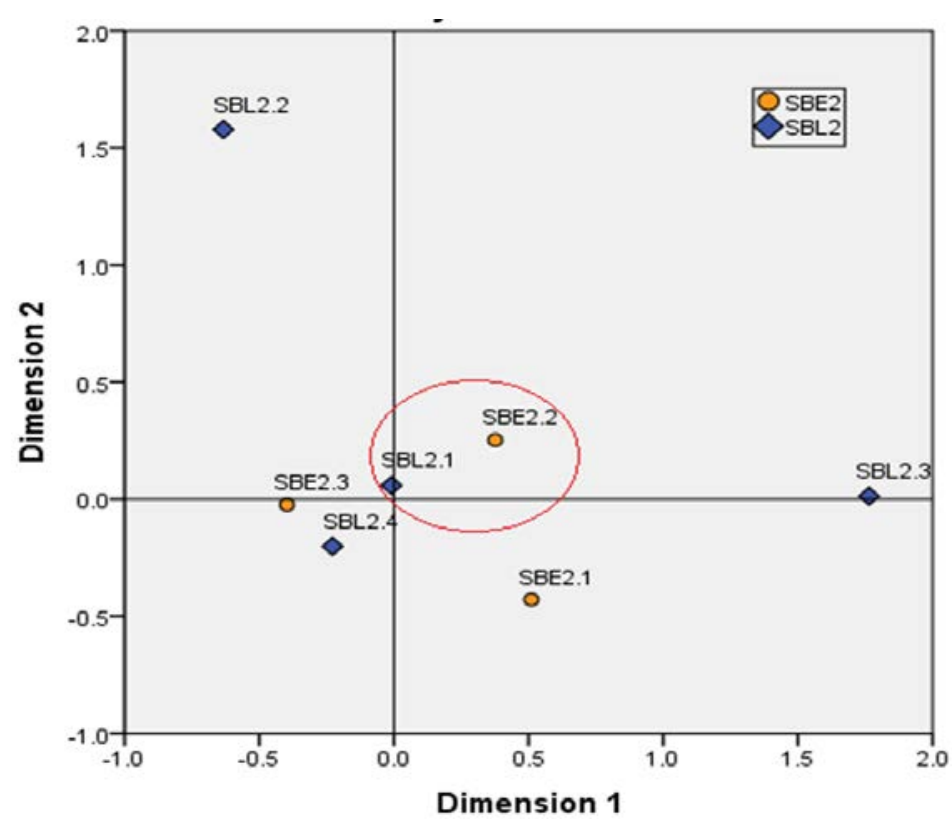

Fig. 5. CA displaying relationship among the categories of SBE2 and SBL2

Based on the results of the study, a revised model is proposed, which is depicted in Fig. 6.

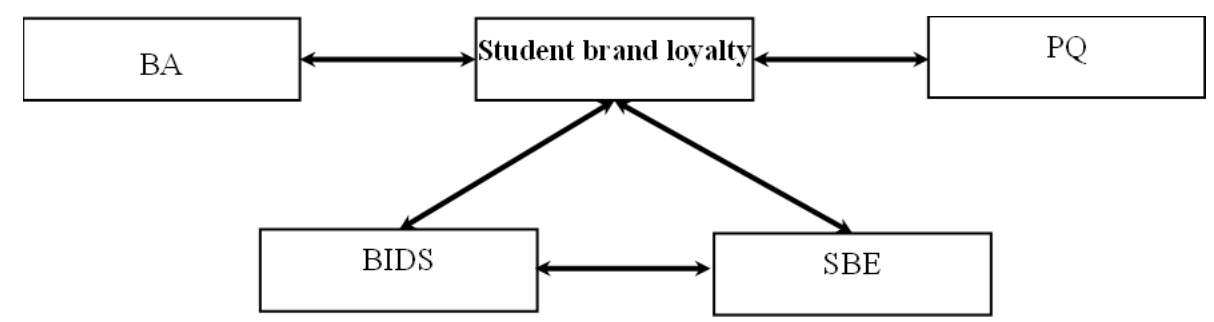

Fig. 6. Revised model for SBL, revealing the confirmed relationships of the constructs

\section{Conclusions and implications}

The goal of the current paper was to test the relations within student brand loyalty based on four constructs - brand associations, brand information dissemination and sufficiency, perceived quality, student brand engagement. Furthermore, we decided to test the supposed mediating role of SBE by testing its relation with BA, BIDS, PQ, SBL. Based on Aaker's well-known conceptual 
model and prior researches in the context of higher education $[33,34,65,66]$ we included BA and PQ in our research scope. We propose a new idea for differentiating BA for the institutions in the sector of higher education in two groups: (a) identifiers - relations carrying a meaningful importance but not capable of driving forward an educational choice. They are a primary perception constructed in the conscience of its recipients through objective-reality experimentation, a directed influence through direct contact or information received via various communication channels, an accepted understanding among a certain social group or among a larger audience, et al (b) motivators - relations playing an important role in the choice of educational program. They can also reflect objective and/or specifically communicated perceptions but relying on personal characteristics of the individuals for whom those perceptions are decision making motivators. The results of the current research confirmed the expectations for the presence of correlation among SBL and BA, PQ. We discovered that "good reputation" and "positive public prestige of the higher education" are the two most significant brand associations which are motivators for continuing the education in a different master's or doctorate program. The findings also support prior research revealing that there is a correlation between the university reputation and loyalty to institutional brand [31, 67]. In relation to the perceived quality, results agree with the majority of previous works that have reported this significant relationship between the SBL and PQ.

The interest in BIDS was based on the common perception for the importance of brand communications for creating, evolving and enhancing a brand's positioning. The choice of the right message and media vehicle is critical to create high brand awareness and preference among stakeholders (e.g. applicants) (Sharma, et al., 2013). Therefore, brand information assurance plays a meaningful role in the process of brand communication (e.g. in order to build an identity through social, cultural, political or other meaning; creating trust; maintaining good relations, et al.) with the different target groups. In literature we found a suggestion on a conceptual level but without empirical testing of the correlation among BIDS and other existing variables. We discovered that there is a relationship between brand information dissemination and sufficiency and student brand loyalty. Furthermore, the students who show a certain level of loyalty to the institution brand, are shaped by the university website and their professors.

The inclusion of SBE was necessitated by the suggestion that one of the goals of higher schools is to achieve a sense of gratification amongst students and turn them into stakeholders who exhibit engagement behavior with the brand such as positive word-of-mouth [61]. Our findings for the existence of a relationship between student brand engagement and student brand loyalty corresponds with prior research [11]. Regrettably, we cannot present confirmation of the supposed mediating role of SBE in the model for measuring SBL. The only confirmed relationship is between student brand engagement and BIDS. This can attract researchers' interest and be the subject of future papers.

A number of preceding researches in different business spheres confirm that brand loyalty is an important component of brand equity. The same can be claimed for the higher education sector. Managers and higher educa- 
tion policymakers have to designate the necessary resources for the conduct of constant monitoring of the level of student brand loyalty in relation to the expected future benefits. They should not underestimate the importance of brand associations, perceived service quality, brand information dissemination and sufficiency, student brand engagement in forming a certain level of student loyalty to the institutional brand. The findings of this paper present information which can be useful for the conduct of more focused effort in establishing a student loyalty program.

\section{$6 \quad$ Limitations and future research}

This research was conducted within a classic public university in Bulgaria over a set period - during the beginning of the summer semester of the academic year 2020/2021. We should also point out some of the obstacles we encountered during data gathering. Despite support from the institution's senior management we met definitive denial of cooperation from some of the academic staff. Of course, this problem was predisposed by the fact that the higher school in subject was broad in scope and included different specialists biologists, physicians, chemists, philologists et al, some of whom, as it turned out, have difficulty realizing and processing well enough the idea of gathering such marketing data. Probably if the research was conducted in a specialized higher school with a business profile, the presence and effect from such obstacles would have been more negligible. One possible suggestion for the management of a specific HEI is the introduction of periodic discussions with all staff about the benefits of such activities and or the introduction of a centralized mechanism for gathering the necessary marketing data in the future. Furthermore, due to the imposed strict measures for Covid-19 pandemic, the research was conducted through an online questionnaire and not on paper. It might be possible that the data collection would increase with the use of a paper-based questionnaire.

We would recommend that future research on measuring student brand loyalty relationships include private institutions of higher education. Elements to be expanded upon may include internal agreement, strength of correlation, degree of influence of separate factors on SBL. Another recommendation for future research is to test the correlation among SBL and other composite variables such as brand trust, brand love, student experience, brand community identification. Finally, it would be beneficial in the future to fill the existing research-gap regarding student brand engagement.

For the purposes of this study, the answers of the current students in the studied educational institution were collected. However, the overall monitoring of HEI brand loyalty should also cover the perceptions of other stakeholders candidates, graduates, parents, companies and partner schools, teachers and employees, whose interests and motives may not coincide with or even be opposite of those of the students. 


\section{References}

[1] Hemsley-Brown, J., Melewar, T. C., Nguyen, B., Wilson, E. J. 2016. Exploring brand identity, meaning, image, and reputation (BIMIR) in higher education: a special section. Journal of Business Research, 69, 3019-3022. DOI: 10.1016/j.jbusres.2016.01.016.

[2] Lafuente Ruiz de Sabando, A., Forcada, J., Zorrilla, P. 2018. The marketing orientation as a university management philosophy: a framework to guide its application. Cuadernos de Gestión, 18(2), 37-58. DOI: 10.5295/ cdg.150576al.

[3] Erisher, W., Obert, H. H., Frank, G. 2014. Brand reputation management within the higher education sector: a review of the literature on higher education brand reputation management, International Research Journal of Marketing, 2(1), 1-8. DOI: 10.12966/irjm.02.01.2014.

[4] Casidy, R., Wymer, W. 2015. The impact of brand strength on satisfaction, loyalty and WOM: An empirical examination in the higher education sector. Journal of Brand Management, 22, 117-135. DOI: https: //doi.org/10.1057/bm.2015.6.

[5] Japutra, A., Keni, K., Nguyen, B. 2016. What's in a university logo? Building commitment in higher education. Journal of Brand Management, 23, 137-152. DOI: https://doi.org/10.1057/bm.2016.1.

[6] Nguyen, B., Yu, X., Melewar, T. C., Hemsley-Brown, J. 2016. Brand ambidexterity and commitment in higher education: an exploratory study. Journal of Business Research, 69, 3105-3112.

[7] Palmer, A., Koenig-Lewis, N., Asaad, Y. 2016. Brand identification in higher education: a conditional process analysis. Journal of Business Research, 69, 3033-3040.

[8] Rauschnabel, P. A., Krey, N., Babin, B. J., Ivens, B. S. 2016. Brand management in higher education: the university brand personality scale. Journal of Business Research, 69, 3077-3086.

[9] Wilson, E. J., Elliot, E. A. 2016. Brand meaning in higher education: leaving the shallows via deep metaphors. Journal of Business Research, 69, 3058-3068.

[10] Mohamad, B., Ismail, A. R., Bidin, R. 2017. Corporate identity management and employee brand support: enhancing marketisation in higher education sector. Jurnal Komunikasi: Malaysian Journal of Communication, 33(3), 178-195. DOI: 10.17576/JKMJC-2017-3303-11.

[11] Salgado, E. G., Vela, M. R. 2019. Brand fan pages experience and strength as antecedents to engagement and intensity of use to achieve HEIS' brand loyalty. Journal of Marketing for Higher Education, 29(1), 1-19. DOI: 10. 1080/08841241.2019.1605437.

[12] Guilbault, M. 2018. Students as customers in higher education: the (controversial) debate needs to end. Journal of Retailing and Consumer Services, 40, 295-298. DOI: 10.1016/j.jretconser.2017.03.006.

[13] Raza, S. A., Qazi, W., Khan, K. A., Shah, S. M. M. 2021. Student as customer concept: an approach to determine Pakistani students' preferences as customers while studying at private universities. International Journal of Educational Management, 35, 2, 513-531. DOI: 10.1108/IJEM-04-20190138. 
[14] Guilbault, M. 2016. Students as customers in higher education: reframing the debate. Journal of Marketing for Higher Education, 26(2), 1-11. DOI: $10.1080 / 08841241.2016 .1245234$.

[15] Rashid, T., Raj, R. 2006. Customer satisfaction: relationship marketing in higher education e-learning. Innovative Marketing, 2(3), 24-34.

https://www.researchgate.net/publication/265429281_Customer_Satisfaction Relationship_Marketing_in_Higher_Education_E-Learning.

[16] He, X., Huang, S., Li, T., Zhhao, K. 2017. a study of interactive style on students loyalty in science technology education: moderating of management level. EURASIA Journal of Mathematics Science and Technology Education, 13(8), 4689-4700. DOI: 10.12973/eurasia.2017.00959a.

[17] Rodrigues, A.S., Ferreira, J., Sousa, P., Quintas, C., Amorim, M., Carvalho, A., Carvalho, F., Rocha, M., Saraiva, L. 2019. Attractiveness, loyalty and student satisfaction in Polytechnic Institute of Viana do Castelo, Portugal. International Journal for Quality Research, 13(4), 1005-1020. DOI: 10.24874/IJQR13.04-17.

[18] Erdoğmuş, İ., Ergun, S. 2016. Understanding university brand loyalty: the mediating role of attitudes towards the department and university. Procedia - Social and Behavioral Sciences, 229, 141-150. DOI: 10.1016/j. sbspro.2016.07.123.

[19] Hossain, S., Sakib, N. 2016. The impact of social media marketing on university students' brand loyalty, International Journal of Marketing and Business Communication, 5(3), 1-7. Retrieved from http://www. publishingindia.com.

[20] Beneke, J. H, BusSc, B., BusSc, M. 2011. Marketing the institution to prospective students - a review of brand (reputation) management in higher education, International Journal of Business and Management, 6(1), 29-44. Retrieved from www.ccsenet.org/ijbm.

[21] Andrlic, B., Budic, H., Pismis, V. 2013. Customer satisfaction as a marketing concept in higher education, Scientific Annals of the "Alexandru Ioan Cuza" University of Iaşi Economic Sciences, 60(1), 1-10. DOI: 10. 2478/aicue-2013-0012.

[22] Nicolescu, L. 2009. Applying marketing to higher education: scope and limits. Management \& Marketing, 4(2), 35-44. Retrieved from http:// www.managementmarketing.ro/pdf/articole/134.pdf.

[23] Ahmmed, M. 2013. Higher education in public universities in Bangladesh, Journal of Management and Science, III(2), 182-190. DOI: 10.26524/jms. 2013.24.

[24] Budac, C., Baltador, L. 2013. The value of brand equity, Procedia Economics and Finance. 6, 444-448. DOI: 10.1016/S2212-5671(13)00161-5.

[25] Aaker, D. 1996. Building strong brands, The Free Press, New York, NY.

[26] Odin, Y., Odin, N., Valette-Florence, P. 2001. Conceptual and operational aspects of brand loyalty: an empirical investigation. Journal of Business Research, 53, 75-84.

[27] Jacoby, J., Kyner, D. B. 1973. Brand loyalty vs. repeat purchasing behavior. Journal of Marketing Research, 10(1), 1-9. DOI: 10.2307/3149402.

[28] Kabiraj, S., Shanmugan, J. 2010. Development of a conceptual framework for brand loyalty: a Euro-Mediterranean perspective. Journal of Brand Management, 18, 285-299. DOI: https://doi.org/10.1057/bm.2010.42. 
[29] Gulid, N. 2011. Student Loyalty Toward Master's Degree Business Administration Curriculum At Srinakharinwirot University. American Journal of Business Education, 4(8), 49-56. DOI: 10.19030/ajbe.v4i8.5302.

[30] Heo, C. Y., Lee, S. 2016. Examination of student loyalty in tourism and hospitality programs: a comparison between the United States and Hong Kong. Journal of Hospitality, Leisure, Sport $\&$ Tourism Education, 18, 69-80. Retrieved from https://www.cabdirect.org/cabdirect/abstract/ 20163220402.

[31] Haqka, E. F., Setiadi, R., Siswantining, T. 2017. Modeling the relationship of factors that shaped student's loyalty. Journal of Physics: Conference Series, 1442, 1-5. DOI: 10.1088/1742-6596/1442/1/012036.

[32] Hennig-Thurau, T., Langer, M. F., Hansen, U. 2001. Modeling and managing student loyalty: an approach based on the concept of relationship quality. Journal of Service Research, 3(4), 331-344.

[33] Ismanova, D. 2019. Students' loyalty in higher education: the mediating effect of satisfaction, trust, commitment on student loyalty to Alma Mater. Management Science Letters, 9, 1161-1168.

[34] Hassan, S., Shamsudin, M. F., Hasim, M. A., Mustapha, I., Buang, R. R., Wahab, M. I. A. 2020. Empirical study on student satisfaction as mediator between service quality and student loyalty in TVET HLIs. Journal of Critical Reviews, 7(8), 122-126.

[35] Stensaker, B., Kehm, B. M. 2009. Introduction, in Kehm, B. M. and Stensaker, B. (Eds.), University rankings, diversity, and the new landscape of higher education, Sense Publishers, Rotterdam, p. vii-xix.

[36] Helgesen, Ø., Nesset, E. 2007. Images, satisfaction and antecedents: drivers of student loyalty? a case study of a Norwegian University College. Corporate Reputation Review, 10, 38-59. DOI: 10.1057/palgrave.crr. 1550037.

[37] Dass, S., Popli, S., Sarkar, A., Sarkar, J. G. \& Vinay, M. 2020. Empirically examining the psychological mechanism of a loved and trusted business school brand, Journal of Marketing for Higher Education. DOI: 10.1080/ 08841241.2020.1742846.

[38] Dimitrova, T., Desev, K. 2020. Measurement model of brand loyalty within the higher education sector. Balkan Scientific Review, 4(2)(8), 49-53. DOI: 10.34671/SCH.BSR.2020.0402.0012.

[39] Paul, R., Pradhan, S. 2019. Achieving student satisfaction and student loyalty in higher education: a focus on service value dimensions. Services Marketing Quarterly, 40(3), 245-268. DOI: 10.1080/15332969.2019. 1630177.

[40] Aaker, D. 1991. Managing brand equity: capitalizing on the value of a brand name, The Free Press, New York, NY.

[41] Severi, E., Ling, K. C. 2013. The mediating effects of brand association, brand loyalty, brand image and perceived quality on brand equity. Asian Social Science, 9(3), 125-137. DOI: 10.5539/ass.v9n3p125.

[42] Keller, K. L. 1993. Conceptualizing, measuring, and managing customerbased brand equity. Journal of Marketing, 57(1), 1-22. DOI: 10.2307/ 1252054 . 
[43] Tran, K. T., Nguyen, P. V., Thi Sa Do, H., Thi Nguyen, L. 2020. University students' insight on brand equity. Management Science Letters, 10, 2053-2062. DOI: 10.5267/j.msl.2020.2.006.

[44] Parasuraman, A., Zeithaml, V.A., Berry, L. L. 1985. a Conceptual model of service quality and its implications for future research. Journal of Marketing, 49, 41-50. DOI: 10.2307/1251430.

[45] Parasuraman, A., Zeithaml, V. A., Berry, L. L. 1988. SERVQUAL: a multiple"=item scale for measuring consumer perceptions of service quality. Journal of Retailing, 64(1), 12-40. Retrieved from https://www. researchgate.net/publication/225083802_SERVQUAL_A_multiple-_Item _ Scale for measuring consumer perceptions of service quality.

[46] Nguyen, T. D., Barret, N. J., Miller, K. E. 2011. Brand loyalty in emerging markets. Marketing Intelligence \& Planning, 29(3), 222-232. DOI: 10. $1108 / 02634501111129211$.

[47] Alhaddad, A. 2015. Perceived Quality, Brand Image and Brand Trust as Determinants of Brand Loyalty, Journal of Research in Business and Management. 3(4), 01-08. Retrieved from www.questjournals.org.

[48] Han, H., Nguyen, H. N., Song, H., Chua, B. L., Lee, S., Kim, W. 2018. Drivers of brand loyalty in the chain coffee shop industry. International Journal of Hospitality Management. 72, 86-97. DOI: 10.1016/j.ijhm.2017. 12.011.

[49] Purgailis, M., Zaksa, K. 2012. The impact of perceived service quality on student loyalty in higher education institutions. Journal of Business Management, 6, 138-152. DOI: 10.5539/ibr.v8n5p81.

[50] Calvo-Porral, C., Lev́y-Mangin, J-P., Novo-Corti, I. 2013. Perceived quality in higher education: an empirical study. Marketing Intelligence \& Planning, 31(6), 601-619. DOI: 10.1108/MIP-11-2012-0136.

[51] Trowler, V. 2010. Student engagement literature review, The Higher Education Academy, York.

[52] Taylor, L., Parsons, J. 2011. Improving student engagement. Current Issues in Education, 14(1), 1-32. Retrieved from http://cie.asu.edu/.

[53] Matthews, K.E. 2016. Students as Partners as the Future of Student Engagement. Student Engagement in Higher Education Journal, 1(1), 15. Retrieved from https://sehej.raise-network.com/raise/article/view/380.

[54] Ahmad, Z., Menon, A. S., Mason, C., Shamsudin, M. F., Sentosa, I. 2020. Does Social Media Engagement Moderate Brand Engagement and Brand Loyalty? Evidence from Young Consumers of Malaysian Modest Fashion Industry, International Journal of Psychosocial Rehabilitation, 24(2), 2500-2508. DOI: 10.37200/IJPR/V24I2/PR200546.

[55] Dwivedi, A. 2015. a higher-order model of consumer brand engagement and its impact on loyalty intentions. Journal of Retailing and Consumer Services, 24, 100-109. DOI: 10.1016/j.jretconser.2015.02.007.

[56] Gong, T. 2018. Customer brand engagement behavior in online brand communities. Journal of Services Marketing, 32/3, 286-299. DOI: 10. 1108/JSM-08-2016-0293.

[57] Kumar, V., 2020. Building Customer-Brand Relationships through Customer Brand Engagement. Journal of Promotion Management, 26(7), 986-1012. DOI: 10.1080/10496491.2020.1746466. 
[58] Khan, I., Rahman, Z., Fatma, M. 2016. The role of customer brand engagement and brand experience in online banking. International Journal of Bank Marketing, 34(7), 1025-1041. DOI: 10.1108/IJBM-07-2015-0110.

[59] Leckie, C., Nyadzayo, M. W., Johnson, L. W. 2016. Antecedents of consumer brand engagement and brand loyalty, Journal of Marketing Management, 32(5-6), 558-578. DOI: 10.1080/0267257X.2015.1131735.

[60] Rather, R. A., Sharma, J., Itoo, M. H. 2018. Exploring relationships among customer brand engagement, brand equity and brand loyalty towards hospitality brands. Abhigyan, 36(2), 41-51. Retrieved from https:// www.researchgate.net/publication/331583450_Exploring_Relationships_Among _ Customer_Brand_Engagement_Brand_Equity_and_Brand_Loyalty_ Towards_ Hospitality_Brands_ntroduction.

[61] Farhat, K., Mokhtar, S. S. M. \& Salleh, S. M. 2020. Role of brand experience and brand affect in creating brand engagement: a case of higher education institutions (HEIs), Journal of Marketing for Higher Education. DOI: $10.1080 / 08841241.2020 .1759753$.

[62] Hollebeek, L. D. 2011. Demystifying customer brand engagement: Exploring the loyalty nexus. Journal of Marketing Management, 27(7-8), 785-807. DOI: 10.1080/0267257X.2010.500132.

[63] Keller, K. L. 2009. Building strong brands in a modern marketing communications environment, Journal of Marketing Communications, 15(2-3), 139-155. DOI: $10.1080 / 13527260902757530$.

[64] Johnson, R.A., Wichern, D. W. 2007. Applied Multivariate Correspondence Analysis, Prentice-Hall, New Jersey, NJ.

[65] Chikazhe, L., Makanyeza, C. \& Kakava, N. Z. 2020. The effect of perceived service quality, satisfaction and loyalty on perceived job performance: perceptions of university graduates, Journal of Marketing for Higher Education. DOI: 10.1080/08841241.2020.1793442.

[66] Perin, M. G., Sampaio, C. H., Simões, C. \& Pólvora, R. P. 2012. Modeling antecedents of student loyalty in higher education, Journal of Marketing for Higher Education, 22(1), 101-116. DOI: 10.1080/08841241.2012. 705797.

[67] Khoshtaria, T., Datuashvili, D. \& Matin, A. 2020. The impact of brand equity dimensions on university reputation: an empirical study of Georgian higher education, Journal of Marketing for Higher Education, 30(2), 239-255. DOI: 10.1080/08841241.2020.1725955. 